\title{
Copyright Protection and Distance Librarianship: provisions and constraints observed in copy right law of Sri Lanka
}

\author{
Damayanthi Gunasekera \\ BA (Kelaniya), MLS (Colombo)
}

\begin{abstract}
The article discuses the existing copyright act and its provisions and barriers that are connected with distance librarianship. The key role of the distance librarianship is facilitating equality of access to information and resources to remote learners in this digital environment. Librarians have to take measures to fulfill different user needs in an environment where there is a balance between the rights of the creators and the needs of users. Further, article discusses about how distance librarianship is affected by copyright law. The act has neglected the distance librarianship in the area of reproduction. Service providers have to support distance learners equally while respecting the ownership. Finally, the paper presents the solutions for the copyright problems and steps that should be taken to get rid of those legal problems by the service providers.
\end{abstract}

Key words: $\quad$ Copyright protection, copyright history, Distance librarianship, Library services,

\section{Introduction}

Rapid changes in the nature of education and communication have drawn greater attention to the vital relationship between copyright law and the success of teaching, research and library services. Copyright Law helps entrepreneurs to become multi-millionaires and thousands of teachers, scholars, readers and librarians to meet their goals every day. Today intellectual community is creating new work and shares those with others by

' Senior Assistant Librarian, Open University of Sri Lanka, Nawala, Nugegoda. E-mail: hpsgun@ou.ac.lk 
selling, freely distributing and making them freely available on the Internet. In the same way librarians also use works created by different scholars and professionals with complex issues under fair use and distribute information among their clients. Further, there appears to be a clash between changes that are happening in the information Communication Technology (ICT) world, with the Internet and original ownership. The main reason for this clash is the Internet which provides unparallel opportunity to exchange information. Scotte (2004) states about the rights of the creators and the ICT facilities as follows:

"Digital technology and internet communication might be referred to as double-edged swords. On the one hand these technologies provide the mechanisms for text to be created, manipulated, searched and communicated over long distances at great speeds. The other side of this sword is the potential for ignoring the fundamental rights of the author/creator to have the work they created honored and not changed or distorted and to receive their appropriate economic return". (Scotte, 2004, p.293)

Due to that, creators are more concerned about protecting their own rights today than in the past.

According to Pedley,

"Copyright is a property right which arises automatically on the creation of various categories of work, and protects the rights and interests of the works, sound recordings, films, broadcasts, and cable programmes and the typographical arrangements of published editions". (Pedley, 2000, p.1)

Copyright law which is a branch of IP law protects a wide range of "works" against unauthorized exploitation in various forms (Hemaratne, 2009, p.47).

The Commonwealth of Learning defines the copyright in distance learning setup in the following way;

"In any teaching and learning environment, but particularly in a distance learning situation, a key issue for teaching and administrative staff in the development and presentation of student materials is copyright" (The Commonwealth of Learning,2000, p.258) 
Intellectual community is affected by copyright, whether a writer or instructor creating original material, or a student or teacher who uses the material. All should respect the ownership. This respect is essential in marinating a balanced and regulated flow of knowledge. Therefore, it can be said that copyright law provides a measure of insurance for the continued output of original works and the creative efforts from which we all benefit.

Due to that, librarians have to balance between the rights of copyright holders and the needs of users of copyrighted materials. Thus, many librarians find themselves in a dilemma of abiding by existing copyright legislation, while trying to meet the growing information needs of their users.

\section{Literature survey}

\subsection{History of copyright protection}

The origin of copy right has been linked to the invention of printing press in the fifteenth century. With the development of printing press, the creation of multiple copies at low cost was possible and copies were distributed among public. Due to economical benefits, at the end of the fifteenth century, competition among printers has increased and piracy of copyrighted work was also born. Therefore, it became increasingly difficult to protect the rights of the original copyright holders.

Due to that society pressed for some kind of copyright protection at the end of 15th century. As a result of that the draft, 'Queen Anne's Statute' was introduced in England in 1710. In 1883, the Paris convention was formulated to find a solution for the copyright violation.

The first major international agreement with the goal of bringing some order into the situation was the Berne Convention of 1886. The general idea of this agreement, signed in September 1887, was to provide authors and publishers whose works were registered in one signatory country the same level of copyright protection in another signatory country as authors in that country without requiring any further formalities. 
The World Intellectual Property Organization (WIPO) was established in 1970. WIPO represents its member countries, administers 23 intellectual property treaties, six of which deal with copyright. The most recent major initiative of WIPO is the WIPO Copyright Treaty of December 1996 dealing with issues primarily flowing from the digital environment.

Another important copyright convention is the Universal Copyright Convention adopted in Geneva in 1952 and revised in Paris in 1971, which was administered by UNESCO. (Scott, 2004, p.211).

It was difficult to meet necessities of some cases regarding copyright issues at national and regional level with the Berne Convention. Due to that World Trade Organization (WTO) has introduced Intellectual Property on the WTO web page stating "ideas and knowledge are an increasingly important part of trade". (www.wto.org/english)

There are two WTO treaties that could affect library services. The first is the General Agreement on Trade and Services (GATS) of 1994. The other treaty, which is more related to copyright, is the Agreement on Trade Related Aspects of International Property Rights (TRIPS) of 1995. The goal of the TRIPS is to narrow the gaps in the way these rights are protected around the world, and to bring them under common international rule. It is important to mention here that the library community operates internationally and in effect speaks with a forceful-united-voice. All member counties of the WTO are interested to adopt a national copyright legislation instead of using the international one. The Digital Millennium Copyright Act of 1998 (USA) created a new set of arrangements in an attempt to prevent further abuse of illegally made electronic copies, their wide distribution in using new recording technologies, or taking advantage of the growing, and largely free computer networks. This has created many ambiguities and limitations in fair use in academic institutions. This became a critical concern for many in the academic institutions when the spreading use of distance education technologies constantly evoked more troublesome aspects of the new law. This issue was directed to the Library of Congress to investigate the matter, and report back on specific changes to the legislation that would balance the 
conflict needs of fair use and copyright protection within the burgeoning area of distance education. As result of that report (Report on Copyright and Digital Distance Education) the Technology Education and Copyright Harmonization (TEACH) act was introduced in 2000. (Lipinski, 2003, p.363).

\subsection{Distance Librarianship and Copyright Protection}

Watson describes distance librarianship as "the professional and nonprofessional activities, procedures, services and practices that proactive quality library and information services to all those who learn at distanceregardless of the level of the education programme" (Watson, 1996). This definition hints different roles of the LIS profession who operates it. Librarians who work in a distance learning environment have to act beyond the traditional role and add many more roles to the profession. It is a real challenge for them.

Further, it became evident that the traditional role played by the librarian is not sufficient at all for the modern library because the libraries and their role in the society are changing rapidly due to the development of the ICT. Shachaf emphasizes the importance of obeying the copyright laws when performing the role of the librarian :

"Librarians must be at the frontline of the intellectual property wars" but author does not specify what role they should play in this war. Further, librarians can take an active role by joining creators lowners or users and engage in fighting. They can serve as moderators who promote peace or maintain cease-fire between each side. They can also play more passive roles by observing and reporting the war or by remaining uninvolved. Whatever the role of librarians is, it is clear that they should follow their ethical guidelines and comply with copyright laws". (Shachaf, 2006, p.96)

Copyright is an issue which affects all teaching situations. But what is the particular significance of copyright in distance learning?. The defining features of distance education are the distance that exists between the learner, their peers, their tutors and the institution of instruction. These are fundamental differences between traditional education and distance education. LIS profession which prevails in distance mode environment is directly related to the need to bridge the distance that exist between library facility provider and 
clients. The main difference of the role between traditional librarian and distance librarian is the pattern of dissemination of information.

In a face-to-face teaching situation, use of some copyright material is allowed without permission as the lecturer physically delivers the content. However, in a distance learning environment all the materials are delivered directly to the student through a medium; consequently the material must be copied, due to that, and the copyright law must be followed.

There are international conventions, such as Digital Millennium Act and TEACH Act (USA) that gives more opportunities to the European distance educational set up. TEACH Act (Lipinski,2003, p.363) has given more performance and display right to the users who are in both face-to face educational and distance learning environments. It has removed the barrier of 'physical classroom' concept and has extended displaying of analog pictures (maps, charts, graphs, visual work) to mediated instructional activities.

Crews discuss the importance of the TEACH Act and states that the fundamental objective is to strike a balance between protecting copyrighted works while permitting educators to use those materials in distance education. Further, he states that TEACH Act does not mention the duties of the librarian but new opportunities to offer distance education programmes are given there.

\section{Main provisions and constraints in the Sri Lankan act}

In Sri Lanka, the copyright law is governed by the Intellectual Property Act, No. 36 of 2003. (Intellectual Property Law, 2004). The copyright law incorporated in this act is relevant to literary, artistic and scientific work, which the act regards as original intellectual creations in the literary, artistic and scientific domain.

It protects only the ways and formats of expression of ideas or information and not the ideas or information. For egg. Two officers of the Sri Lankan Army, who were at the battle front when war was going on at North East, write two books stating their experiences on "Demolition of LTTE leader". As both of them are writing on one incident, same facts, information and experiences are 
described in these two publications. But the way of intellectual expressions and presenting facts, ideas and information is different. That difference is protected by the law during a specific period. Hence copyright protects the way of expression of ideas not the information or facts. Such protection is essential in order to ensure authors protection for their creative work during a specified time and simultaneously ensure societal rights to access to original information.

This protection automatically starts at the moment of creation of the work. Protection is granted for the works in general for author's life time and further period of 70 years from the date of his death. (IP Act. No. 36 of 2003)

E.g. a book titled "Higher education policy in Sri Lanka: New Perspectives and Change by Wiswa Warnapala. The protection of copyright of this work starts just after creation of this book and it prevails until the life time of the author and 70 years after the date of author's death. But the author has the right to transfer that copyright ownership to some other person, sometimes it may be a publisher, another co-author or any other organization. If the author has not protected his ownership, automatically it will pass to the spouse or a close relative after the author's death and it will prevail on the completion of seventy years. Hence that, author or any other authorized person can take legal actions if any one damages or misuses the creativity of the work during that period. The author can take following actions whenever an infringement is detected.

(a).Complain to the police about the alleged infringement and thereafter file a civil action against the perpetrator.

(b).Get a copy of the infringed work using a decoy and make an application to the Magistrate's courts to obtain a search warrant in order to seize the infringed work.

(c). Complain to the Director General of Intellectual Property (Hemaratne, 2000, p.2)

But if you take a book titled "Selalihini Sandeshaya" written by Thotagamuwe Rahula Thero, in Kotte Period, the copyright protection period has expired 
now and legal action cannot be taken against the reproduction or misuses of the creativity of this work.

The Sri Lankan Copyright Laws extend to protect work including,

(a) books, pamphlets, articles, computer programmes and other writing,

(b) Speeches, lectures, addresses, sermons and other oral work,

(c) Dramatic, dramatic-musical works, pantomimes, choreographic work,

(d) Musical works with or without accompanying work,

(e) Audiovisual work,

(f) Works of drawing, painting, sculpture, engraving, lithography...other work of fine arts,

(g) Photographic work,

(h) Work of applied arts,

(i) Illustration, maps, plans, sketches.... . (Intellectual Property Law of 2003 No.36,2004)

In addition to that, the copyright law protects derivative work such as

a) translations, adaptations, arrangements and other transformations or modifications of works.

b) Collection of work and collection of mere data bases, whether machine readable or other forms. (Intellectual Property Law of 2003 no.36, section 07,2004 )

The law states that the author who created the particular work is regarded as the original owner of copyrighted work. However, the owner has two rights,

1. economic rights and

2. moral rights. (Intellectual Property Law of 2003 no.36,2004)

The economic right means that the owner has the exclusive right to engage in any activity such as copying the work, issuing copies to the public, performing it in public, broadcasting it, and adapting it etc..

The author of the literary work has rights to object to any distortion, mutilation or other modification etc. through moral rights. This shows that more facilities and benefits are given to authors not to the users by Sri Lankan copyright act and by the TRIPS agreement. 
Fair use is another right given by the act to information users. Users can use any literary work for purposes such as criticism, commenting, news reporting, educational and research activities without getting permission from the copyright owner. However, this particular use depends on four factors,

a) the purpose and character of use,

b) the nature of copyright work,

c) the amount and substantiality of portion used in relation to the copyrighted work,

d) effect of the use upon the potential market for, or value of the copyrighted work.

The act further permits the following activities under fair use only for the people who engage in teaching and learning activities:

- quotation of a short part from copyrighted work,

- adaptation of a computer programme by the lawful owner of a copy of that programme.

- reproduction of a single copy of printed or AV material,

- reproduction of a short part from the copyrighted work for teaching purposes,

- reproduction for library and archival purposes,

- reprographic reproduction for face-to-face teaching in any educational institution.

\section{The OUSL Library services \& Copyright protection}

Service providers need basic infrastructure facilities and other facilities such as law, technology, administration and management procedures at the parent institution to provide equal support to distance learners.

New technology and computer software have given more opportunities to OUSL library to share, to reproduce, and to transmit any information irrespective of its original format. E-resources available in the OUSL library web site can be accessed through intranet and www.

But the OUSL library is faced with the problem of providing some essential resources online to distance learners due to copyright law. Distance learners 
have to come to the main library to use resources that can be accessed through the intranet or they can request from the library. Coming to Colombo from faraway places is difficult and they should be given access to all resources on online. E.g. One of the objectives of establishing Virtual Resource Centre (VRC) in 2007 at OUSL main library was to develop access to databases and to deliver information through the electronic media (Korale, 2003 , p.2). It is a question whether that objective has been achieved or not due to constraints of the copyright law. In addition to that OUSL has turned a new chapter by introducing online programmes such as MATE international programme, CEMBA in 2008 and were expected to support learners online.

Under such situations, it is difficult to play even key roles that are assigned to distance librarianship. The other main constraint is that the Sri Lankan copyright act particularly mentions that the 'reprographic reproduction facility is available under fair use, but it can be applied for face-to-face teaching environment only and not for other educational environments (Intellectual Property Law of 2003 no.36, 2004).

The definition given for the word "reprography" is "a technique of making single or multiple copies of an original document using photography or any other technical process". (Wimalaratne, 1980, p.229).

It is difficult to ignore today, the advantages of a reprography service to the library and its readers with the higher demand for information especially in elearning environment in distance education setup.

The efficiency of a library lies in its findings information which enables to render a good reference service to the users. Therefore, reprographic reproduction is an essential facility to libraries where information is disseminated at a low cost and in a speedy manner as it supports to collect materials to render good reference service online and offline.

It is one of the main constraints that the OUSL library is facing today. Even though the reproduction facility is given by the law, service providers can apply that issue and can help users. But the problem is that the OUSL library cannot give photocopying service as a public service due that constraint. 
But it is observed that it is an essential service because it was found that $99 \%$ of distance learners who use the main library, have used photocopying service to get copies of the past question papers and text materials.(Seneviratne, 2009)

Due to diverse user needs, many of them want to copy the entire book and AV material. But as copyright protectors, LIS professionals can allow students to do that? It is a question and it depends on the implementation of the law in the country. Under such circumstance, Sri Lankan Librarians who encourage copyright infringements by providing photocopying service has become law breakers.

It is completely against the general accepted principles on LIS professionals with copyright issues. Norman states "LIS professionals are often called upon to administer copyright compliance within their organization. They are seen as the experts in pointing out what is and what is not allowed. Library professionals therefore have a key role in both controlling and facilitating access to information, and as such they also have to be able to explain to their users what levels of copying are permissible under copyright legislation in some instances" (Norman,1990, p.128).

As it is an essential service in 'knowledge industry' particularly to the distance learners, it cannot be stopped. The danger in that is, LIS professionals are liable to offence at any time on any day.

Further, it was observed by Amarasuriya and states in her presentation that 'It is observed that many library users, students as well as academic staff, are not aware of the existing copyright law and its limitations and protections that are available in an educational environment' (Amarasuriya, 2009) The author also has the same experience being In Charge of Reader Services Section since 2004 and through the inquire made by students and staff and complaints made by library staff about the copying of whole material. 
However, the Sri Lankan law has not given the rationale of the law and it shows so many restrictions to access knowledge, especially in areas involving new technologies. The OUSL library makes copies of the OUSL AV production and accompanying materials for the purpose of preserving the materials. Copying of accompanying materials is a problem as it has not been clearly mentioned in the act. Communicating the work by electronic means is also not properly defined by the act. OUSL library digitize materials by scanning and makes those materials available on website. But the existing provisions of the act are not clear enough to protect certain new developments such as internet, sharing of digital resources etc. This has been pointed out by Karunaratne (2000, p.7) in his article as, "the existing provisions appear to be not sufficient to deal with the issues originated in the new digital environment, particularly the Internet". Cabral (2004, p.12) observes that the Internet has been described as 'the world's biggest copy machine'.

That means, LIS professionals sometimes have to be lawyers as well as the copyright police because they have to control usage or stop the misuse of resources while encouraging access to information. It is a negative fact to mention that authorities who amend the acts and legislations have not paid their attention on different modes of teaching and learning environments that are available in the country when amending the copyright act in 2003 though the distance mode of teaching has started in 1976 by the Sri Lanka Institute of Distance Education (SLIDE) in Sri Lanka.

\section{Discussion}

The government of Sri Lanka has emphasized equal education rights for all citizens by the constitution but the provision of facilities that are needed to acquire knowledge is restricted by the law. Even though the government has recognized the economic value of the distance mode of teaching and learning, relevant policies were not properly formulated to combine all the educational settings such as distance, vocational and higher education by the Ministry of Education. Therefore, it shows the contradiction between the educational rights given by the constitution and rights to information access. However, LIS professionals cannot serve their users under such circumstances and have to 
find a solution for that. For that they have to inform relevant authorities to formulate new policies and amend existing rules especially relevant to the distance education and library services to support distance learners equally.

Further, necessary resources should be given to distance learners wherever they live in order to maintain the quality and standard of distance education that are available in Sri Lanka. Service providers are responsible to provide eresources to remote learners because of the cost, online sharing is done to disseminate information at a low cost among distance learners. Infrastructure facilities, which are needed to share information online are available in remote areas through 26 Regional and study centers, and other government Internet access centers like Nanasala and Vidatha centers. Therefore, students can make use of those online resources now without any problem. If copyright law does not allow producing e-resources and access to e- knowledge, both information provider and remote learners are in a problematic situation. Therefore, the goal of the policy makers has been to achieve an appropriate balance in the law, providing strong effective rights, but within reasonable limits and with fair exception.

As mentioned in the literature review, many acts and bills like TEACH act have been passed in other countries as LIS professionals had to face many problems as the law did not allow them to support users. These changes have given more chances to serve distance learners who are away from the classroom. The Sri Lankan government authorities should recognize the importance of those conventions and should try to adapt suitable things to suit our necessities.

Even though the new technology and other facilities have given more opportunities to OUSL library to share information online, still distance learners have to come to library premises to use them due to these copyright complexities.

It is a problem for both to service providers as well as to the users. Therefore, the need for the preparation of new rules according to the necessity of Sri 
Lanka or revisions to the present international rules relating to copyright is highly needed to meet the present complex situation in the country.

The authorities of the Sri Lankan government should recognize the importance of those conventions and should try to adapt suitable things to suit our necessities.

Further, the goal of the policymakers has been to achieve an appropriate balance in the law, providing strong and effective rights, but within reasonable limits and with fair exceptions. Then, these changes will give more chances to serve distance learners who are way from the classroom.

It is observed that $99 \%$ of distance learners who use the main library, have used photocopying service to get copies of the past question papers and text materials (Seneviratne, 2009). Due to diverse user needs, many of them want to copy the entire material even though the law has permitted to copy $5 \%$ of the material. As copyright protectors, LIS professionals cannot allow students to do that. It is a question and it depends on the implementation of the law in the country. Even though the law does not permit to implement reproduction facility in the distance learning setup, LIS professionals are violating the law and have become law breakers by providing photocopying facility inside the library.

As a solution for that, librarians have to introduce a 'Declaration form' to be signed at the library as an agreement and make aware of the authorities by emphasizing the importance of taking measures to amend the law to suite the distance educational setup.

The main problem affecting the library staff, as one of the researchers pointed out, is that unawareness of the existing copyright law and its limitations and protections that are available in an educational environment by the library users. LIS professionals have to have a proper idea about the fair use and its limitations to give proper instructions to the users. For that LIS professionals should be educated on legal issues first by updating LIS syllabuses to suite the current needs of the society. 
Considering all the issues discussed above, the following recommendations can be made.

\section{Recommendations}

Today, information has become a major commodity and diverse needs are becoming increased. Due to availability of quick reproduction facilities, pirated copies are becoming increased. This has started with the objective of earning money. Due to lack of knowledge on IPR and without knowing what is 'copy right' and 'copy wrong', people violate the law making illegal copies. That happens everywhere, in libraries, cybercafés, computer labs, AV centers, record bars etc. in the country and it is uncontrollable.

Therefore,

* New policies specially, regarding distance education, higher education and library services should be formulated to facilitate equal services to all remote learners.

* The separate copyright guidelines for librarians and information professionals should be formulated to promote, respect and understanding of copyright and to help librarians to provide good service to their clientele whilst remaining on the right side of the law.

* Notice regarding copyright limitations can be displayed in the library and declaration form can be placed at the library for users to sign when they want to get more copies than allowed.

* An individual staff member can be appointed as a key connect for copyright queries.

* Clear labeling of items that are not allowed to photocopy can be marked at the catalogue record.

- Sri Lankan copyright act is narrowly defined, it should be elaborated and updated and policies should be changed to suite all educational settings.

* Students and staff of the OUSL should be educated on IPR, copyright law, its limitations and its protection. Copyright limitations should be informed to students at the orientation.

* LIS syllabuses should be updated to educate LIS professionals regarding copyright law.

* Lack of research conducted in Sri Lanka on copyright issues related to LIS professional activities is also one of the main reasons not to publicize the area. Therefore, research activities should be conducted in that field. 


\section{References}

Amarasuriya, H (2009). Presented at the workshop on "Study on Intellectual property regulations and access to knowledge initiatives in Sri Lanka". on $30^{\text {th }}$ April 2009 at OUSL. Unpublished report.

Cabral, H (2004). Intellectual property law in Sri Lanka: the act no. 36 of 2003, the TRIPS agreement and a case digest. Colombo: Harsha Cabral.

Copyright \& distance education: trainer's toolkit, (2000) Suite, The Commonwealth of learning.

Crews, Kenneth D. (2000) Copyright essentials for librarians and educators, Chicago, ALA.

Hemarathne, T. (2009). Introduction to intellectual property laws: presented at the workshop on "Study on Intellectual property regulations and access to knowledge initiatives in Sri Lanka". 30 ${ }^{\text {th }}$ April 2009 at OUSL.

Intellectual Property Law of 2003 no.36. (2004) Colombo: Educational Publications Department.

Karunaratne, D.M. (2000). Copyright under new technologies. Sri Lanka Library Review (New Series) 14 (1).p.6-10.

Korale, S.R. 2003. Establishing a vibrant high tech E-library at OUSL to support academic research and distance education needs in the $21^{\text {st }}$ century, project proposal submitted to the DEMP project. Unpublished report.

Lipinski, T. A. (2003). The climate of distance education in the $21^{\text {st }}$ century: understanding and surviving the changes brought by the TEACH (Technology, Education, And Copyright Harmonization) Act of 2002. The journal of Academic Librarianship.29 (6) 362-374.

Norman,S (1990) Copyright in further and higher education libraries, $3^{\text {rd }}$ ed.,London, ALA,

Pedley, P (2000) Copyright for library and information service professionals, second ed., Aslib,London.

Scott, M. (2004). Copyright and related issues in a global economy In. Martin, Alan, Kesselman \& Irwin Weintraub (2004). Global librarianship. New York: Marcel Dekker.

Seneviratne, W. (2009). Modes of accessing information (Secondary Level) Status. Presented at the workshop on "Study on Intellectual property regulations and access to knowledge initiatives in Sri Lanka", $30^{\text {th }}$ April 2009 at OUSL. (Unpublished) 
Shachaf, Pnina \& Ellen Rubenstein (2006). A comparative analysis of libraries' approaches to copyright: Israel. Russia, and the U.S., The Journal of Academic Librarianship, Vol. 33(1) 94-105pp.

Sharma, J. (2001) Professional competencies in modern libraries, Authors press, Laxmi Nagar, Delhi,

Scott, M (2004). Copyright and related issues in a global economy In Global librarianship. Ed. by. Martin, Alan, Kesselman \& Irwin Weintraub (2004). New York: Marcel Dekker.

Watson, E.F. \& Jaganathan. N (1996) Distance Librarianship in the Commonwealth: a reader, Vancouver: COL. (watsone@uwichill.edu.bb). 